DOI: 10.20472/LPC.2018.003.004

\title{
PETER MIHÓK
}

Univerzita Mateja Bela v Banskej Bystrici, Slovak Republic

\section{MARTIN ORVISKÝ}

Univerzita Mateja Bela v Banskej Bystrici, Slovak Republic

\section{ANNA VAŇOVÁ}

Univerzita Mateja Bela v Banskej Bystrici, Slovak Republic

\section{THE LEGAL ROLES AND PROFESSIONAL ETHICS OF DEFENCE ATTORNEYS IN RELATION TO THE ELECTRONIC MONITORING OF OFFENDERS IN SLOVAKIA (VIS-À-VIS THE SITUATION IN THE USA AND THE EU)}

\begin{abstract}
:
This paper deals with the legal roles, and to a small extent also with the professional ethics of defence attorneys in relation to the use of electronic monitoring in the criminal justice field. Its scientific aim is twofold: (1) to briefly summarize relevant results of the pilot research conducted within the Slovak-national project acronymed IAEMPS, and (2) to compare them with the relevant desk research results concerning the USA and the EU. In the concluding part, the authors open the discussion about the potential shifts of emphasis (a) from technical aspects of EM aimed at replacing imprisonment to electronically monitored probation programs as autonomous sentences; and (b) from 'traditional penal' attorneys to 'more holistic defence attorneys'.
\end{abstract}

\section{Keywords:}

electronic monitoring (EM), attorneys, probation, Slovakia, the IAEMPS project.

JEL Classification: K14, K00 


\section{Introduction}

This conference presentation/ paper is a direct follow up to the presentation/paper from the 2nd Law \& Political Science Conference in Prague, further referred as 'the preceding paper' (Mihók, 2018). The impetus, resp. the inspiration to prepare it came to a large extent from the presentation at the same conference by Katerina Lewinbuk (South Texas College of Law Houston, USA) titled 'Comparative analysis of ethical boundaries and regulations for lawyers in the United States, European Union and Russia / legal profession in a comparative context' (Lewinbuk, 2018). This paper completely abstracts from the situation in Russia, as it is not relevant for the below introduced research project acronymed IAEMPS. Due to the limited capacities of the IAEMPS project for work not directly related to Slovakia, this paper does not present a complete overview of the stateof-the-art, but instead focuses on summarizing relevant impetuses for the further research in this topic in Slovakia in 2019-2020.

This paper if focused on the roles played in relation to electronic monitoring (EM) of accused and/or convicted persons (i.e. offenders) by defending attorneys, both private and public (i.e. the so called 'ex offo' or 'ex office'). I.e. the paper does not deal with the roles of public attorneys (i.e. State attorneys, district attorneys, etc.). The relevant key terms such as EM have already been defined in the preceding presentation/paper (Mihók, 2018), in which also the IAEMPS project has been introduced. The scientific aim of this follow-up presentation/paper is twofold: (1) to briefly summarize the relevant results of the pilot research conducted within the Slovak-national project acronymed IAEMPS in July September 2018 by means of bilateral interviews, and (2) to compare these results with the relevant secondary research results about the situation in the USA and the EU in this field (carried out within the IAEMPS project in the same period). The subject of research were the the legal roles and ethical regulations for the work of defence attorneys that relates to electronically monitored punishments. The objects of primary research (i.e. interviews) were the selected Slovak judges, prosecutors, probation officers and attorneys, and the object of secondary research were the relevant academic, legal and official documents (which are all quoted correspondingly).

The use of EM for a wide range of purposes in the criminal justice field has already been presented in the preceding paper (Mihók, 2018). In short, the original research in the U.S. in the 1960s, and many current EM programs are focused on a probation, the most often with an aim to motivate offenders to complete their 'correction programs' by means of their constant surveillance using the EM devices. Another widely implemented purpose of EM is to monitor house arrests which are imposed as an alternative to short term imprisonments of less dangerous offenders. The development and relatively high price decrease of the global positioning system (GPS) technology allowed several new purposes of the EM use in the criminal justice field, for example the so called bilateral EM (BEM) schemes [also] aimed at alarming former victims of a vicinity of their former 
offenders. In this paper, we abstract from the frequent empiric cases in which judges and/or probation officers are demotivated to impose EM due to technical problems that often occur in relation to the EM devices and/or the problems employing the EM implementation systems, and fully focus on the roles and ethics of defence attorneys under the conditions of fully functional EM programs.

\section{The role of defence attorneys related to EM in the USA}

As we have also introduced in the preceding paper (Mihók, 2018), the EM started to be implemented in the legal practice in the first states of USA already since the 1983. Ten years later, the EM was implemented in all the states of USA (Clear and Dammer, 2000 and Renzema, 1992 in: McKenzie, 2009, p. 319). While for the most of states the motivation arose from jail/prison overcrowding, some states reported that they "wanted to divert low risk offenders and avoid costs (in Florida)", resp. that they were motivated by "awareness of technology and interest in experimentation (in Oklahoma)" (Texas Criminal Justice Policy Council, 1986, Table 2 on p. 59). Several states decided to implement their first EM programs not at a statewide level, but only at a level of counties (Ibid., see Table 1 on p. 58). Until the present, the EM programs in the USA have been implemented at a level of counties, in respect to different counties' judicial systems across the states, as well as with the respect to the rights of counties to cancel funding for EM programs (see for ex.: Daily Herald, 2017). Therefore, generalisations cannot be made about the use of EM in the USA not only at a federal level, but moreover also at the levels of individual states. The legal roles and professional ethics of attorneys in relation to the EM may therefore differ within individual counties of the same state.

Within our secondary research, we found several documents mentioning legal roles that defence attorneys have been provided with in relation to the EM. For example, in the Windham County in the state of Vermont, defence attorneys are being asked to prepare and submit recommendations of acceptance or denial into the EM program together with their reasonings. However, the positions of defence attorneys are not the deciding factors in acceptance of their clients into the EM programs. But when clients are accepted into the EM programs as participants, defence attorneys are being provided with the participants' movement schedules including dates, time, locations and purposes of offenders' movements; and defence attorneys can propose changes in these movement schedules (Windham County Sheriff's Office, 2016, Procedure Number EMP - 007 'Coordinator Responsibility', p. 2 - 3).

The rights and responsibilities of defence attorneys related to EM house arrests of their clients within a particular county can naturally change over the time. For example, under the rules valid in September 2016, the EM program participants in the Windham County were obliged to call the EM program staff at least 72 hours in advance to receive approval prior to any deviation from the submitted schedule (Ibid., Participant Handbook, 
p. 6). This has been changed, and as of January 2017, the program participants must contact their attorneys to have their schedules modified through court proceedings (Windham County Sheriff's Office, 2017, Defendant Handbook, p. 5). Under the amended rules, request that offenders are placed into the EM program are being signed not by the offenders, but by their attorneys (Ibid., Annex to the Procedure Number EMP -007).

Arredondo et al. (2001, p. 9) explained that rights related to EM are assigned to defence attorneys because they play a role of "advocates for a treatment plan which is in the best interest" of the client, while the responsibility of public deputies/defenders are to educate other decision-making bodies about relevant defence considerations. Together with the example of the legal rights provided in the paragraph above, this explanations suggest that the rights related to the EM programs have been given to defence attorneys in the USA in relation to preparations of the most appropriate probation plans for offenders, with an aim to ensure their rehabilitation and eliminate the risk of their recidivism.

While researching publicly available academic literature, we have also found the case report explaining how the defence attorney managed to indirectly influence the judge to choose the EM instead of a detention. This case report concerned the girl named Kathy which was placed under the 'standard probation without EM' after she admitted to a lowlevel drug possession charge. Due to a need to take care about an ill grandmother, whose social security was Kathy's only income and who was the only family member that Kathy could live with, Kathy did not implement any of her probation program and, moreover, got pregnant. In response to the probation violation, the prosecutor requested a detention for Kathy, but her defence attorney objected. "Perhaps trying to appease both sides, the judge placed Kathy on EM" (Weisburd, 2015, p. 321). Afterwards, Kathy finally started to make some progress with her probation program. According to Weisburd, Kathy's case illustrated how "the courts, probation officers, and prosecutors focus more on technical compliance with the EM program" rather than on the offenders' "overall, albeit slow, upward trajectories" (Ibid.), which are naturally much better known to offenders' defence attorneys.

As was presented by Lewinbuk (2018) at 'the preceding conference', the rights and work ethics of attorneys in the USA is significantly less regulated de iure by Laws or official documents than in the EU. Even though the American Bar Association (ABA) publishes 'the Model Rules of Professional Conduct' that contain a broad set best practices and examples of typical ethical violations, these rules are not legally binding at the federal level. While some states have adopted the rules of conduct (and the ethical rules) for attorneys by themselves, the other states use the above mentioned ABA document as a guide in this regards. As Lewinbuck explained, the attorneys in the USA de facto face rather strict regulations implemented by themselves by means of submissions/complaints to the organizations that have rights to grant and withhold licenses to practice the work of attorney in a given state (usually disciplinary boards of given states' supreme courts or specific Agencies). Suspicions that defence attorneys have not acted in the best interests 
of their client may be sufficient grounds for filing such submissions/complaints. And should they be found to be sufficiently grounded, the relevant [state] disciplinary boards/agencies can fine attorneys, force attorneys to attend classes or perform community service, or even take away the licenses to conduct work of attorneys. Therefore, in cases in which electronically monitored house arrests and/or probation plans would be in the best interests of offenders, defence attorneys are de facto motivated to implement all their legal rights [existing in the given county of the given state] in suggesting placements under EM (vis-à-vis other legally available forms of punishments), towards both the clients and the courts/judges. Should they foster preference of other forms of punishments which would be in their own interest (for ex. as they would require less work and/or commitment from them), defence attorneys in the USA would face risks of submissions/complaints to the relevant disciplinary boards/agencies not only from their clients or the judges, but also from defence attorneys aware of the case (for ex. attorneys of victims).

\section{The role of defence attorneys related to EM in the EU}

As we have explained in the preceding paper, a common approach in introducing/implementing national EM programs has not been considered in the EU, and that the recent experience rather suggests that the EU seems to give a carte blanche to its member states in this regards (Mihók, 2018, p. 30). "While some countries preferred punishment based approach predominantly focused on restriction of liberty (i.e. Sweden), other countries preferred to focus on rehabilitative and reintegrative aims (i.e. Netherlands), and development in some other countries has been characterised by a transfer from the former to the latter (i.e. Scotland) or by the mixed focus on both the former and the latter (i.e. England)" (Ibid.).

In comparison with the USA, our desk research carried out within the IAEMPS project resulted in finding only extremely little publicly available academic or official documents mentioning the roles of attorneys in relation to EM. One of the exceptions is the short paragraph in the Netherlands national report from the comparative research project titled 'Creativity and effectiveness in the use of EM: a case study of five European jurisdictions', acronymed the EMEU project (Boone, der Kooij and Rap, 2016). The quoted researchers provided the information that "in some cases [in the Netherlands], defence attorneys take the initiative to ask for a feasibility study on the use of EM on their client. They may direct this request towards the prosecutor, judge or probation service. At the pre-trial stage, for example, a defence attorney may feel that the possibility of imposing EM can increase the chance that the client's pre-trial detention detention will be suspended." (Ibid., p. 13).

Apart from the Netherlands, the only other EU member state for which we found the information about roles of attorneys in relation to EM was Portugal. However, the key 
source (one of the two sources we managed to find) was the national report for the EUwide coverage project titled 'Mapping the legislation and assessing the impact of Protection Orders in the European Member States', acronymed (POEMS), i.e. the source limited to information related to the bilateral use of EM for both former offenders and former victims under the protection orders (APAV, 2015, p. 3). The authors explain that "the imposition of protection orders [in Portugal] does not generally oblige the victim to be represented by an attorney. However, in the case of coercive measures, if the victim wishes to request directly to the judge the imposition or substitution of a protection order he/she will have to become an 'assistant' to the proceeding and in such a case it will be mandatory (Ibid., p. 18). The decisions "concerning the violation of the conditions of the suspension, must both be considered as a final sentence and, in consequence, must be informed to the defendant and his/her attorney. The grounds for such decisions may also be applied to determine that also the victim must be informed about this decision, but only if he/she is an 'assistant' in the proceeding" (Ibid., p. 29). Apart from the POEMS project national report, we found also the slides of the presentation of Pinto de Abreu (unknown year) titled 'The role of the practising lawyer in Electronic Monitoring in Portugal' in which these roles of practising lawyers (i.e. defence attorneys) are listed:

- assessing the legal requisites for EM to be applied (which are different in cases of bail measures, sanctions, adaptation to early releases and modifications of executions of sanctions);

- informing clients of EM requisites, conditions, benefits and contacting third persons who must give consent;

- substantiating the fulfilment of the legal and factual requisites by means of reasoned request to the court;

- asking for exceptional permissions to the court (or EM service);

- eventually using EM services to produce evidence in court (in particular domestic violence cases) (Pinto de Abreu, unknown year, slide no. 6).

As a part of our the desk research carried out by is within the above and below mentioned IAEMPS project, we have used the most relevant internet search engine (i.e. Google, with the key words both '(defence) attorneys' and 'defence lawyers') to seek for the relevant documents not only at the websites of the above mentioned EMEU and POEMS projects, but also at the website of the COST Action no. (IS)1106 titled 'Offender

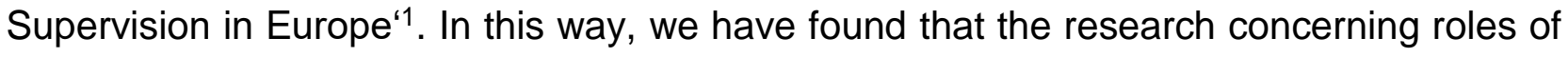
attorneys in sentencing (not specifically in relation to EM, but in relation to all existing forms of offender supervision) was included amongst the joint research activities of the Working Group (WG) 1 of this COST Action (Boone and Herzog-Evans, 2013). The report from this COST WG first year's activities mentions that there is an apparent clear dichotomy with regards to alternative sentences in Europe: "there are, on the one hand,

${ }^{1}$ www.offendersupervision.eu. 
jurisdictions where alternative sentences are autonomous sentences and, on the other hand, jurisdictions where they replace imprisonment, which is not pronounced or can be suspended" (Ibid.). This COST Action reports stated that "we have little knowledge about what type of attorney influence judges" (Herzog-Evans, 2013), resp. "we do not know how influential and under what conditions attorneys are influential in sentencing courts" (Boone and Herzog-Evans, 2013). Moreover, Herzog-Evans (2013) mentioned that "there may be a fascinating dichotomy in this respect between classic penal attorneys and holistic attorneys who develop a form of therapeutic alliance with their clients", together with the information that she planned "a specific research on attorneys in sentences' implementation to test this typology" (note: we were unable to find any additional information in relation to this planned research).

The work of defence attorneys in the EU is regulated by the Code of Conduct for European Lawyers, promulgated by the Council of the Bars and Law Societies of the European Community (CCBE). It is a binding text for all the member states of the CCBE: "all lawyers who are members of the bars of these countries (whether their bars are full, associate or observer members of the CCBE) have to comply with the Code in their cross-border activities within the European Union, the European Economic Area and the Swiss Confederation as well as within associate and observer countries" (CCBE, 2013, p. 1). The principle that "a lawyer must always act in the best interests of the client and must put those interests before the lawyer's own interests or those of fellow members of the legal profession" is a part of this Code (Ibid., p. 16; see also: p. 27). Within our desk research, we were unable to find the term 'electronic monitoring' in this Code. While performing the search of this term in the texts and documents at the webpage of CCBE using the standard internet search engine (i.e. Google), we found only one CCBE document containing this term (several times) - the Final Report of the AW-Rights project titled 'Analysis of the implementation of and operation of the European Arrest Warrant from the point of view of defence practitioners' (Goldsmith, 2016). From the title of the document it is clear that it concerns the work of 'defence practitioners', i.e. [defence] attorneys. With regards to pre-trail detention, this report states that "there should be more use of EM, and further consideration should be given to promoting other alternatives to detention at EU level, including bail and voluntary surrender" (Ibid., p. 10 and p. 36). Other than that, this report only mentions EM either amongst good practices used in some EU member state, with the one exception of the case ${ }^{2}$ in which the time that the Polish citizen spent under the EM in the United Kingdom has been interpreted as 'a restriction of liberty' and not as 'a deprivation of liberty'. Due to such interpretation, the period which this Polish citizen spent under the EM in the U.K. has not been deducted by the Polish authorities from the time that he had to subsequently spend under detention in Poland, with an explanation that only the measures equivalent to imprisonment must be

2 The judgement by the Court of Justice of the European Union no. C-294/16 PPU in the case of JZ v Prokuratura Rejonowa Łódź-Śródmieście. 
deducted (Ibid., p. 33). This case report implicitly suggests that placing under EM, as an alternative to detention in jail, may not in the end turn out to be in the best interest of the offender from the EU who committed a crime in the other EU member state than the country of his citizenship (resp. permanent residence). The results of the IEAMPS project research presented in this section provide another set of reasons to assume that the EU gives a carte blanché to its member states with regards to the use of EM, with the respect to how defence attorneys implement the best interests of their clients in this regards.

\section{The role of attorneys related to EM in Slovakia}

As has already been introduced in the preceding presentation/paper, "the first impetus to prepare the Slovak national EM program came from the Ministry of finance in 2010, in the context of the measures proposed with an aim to increasing the efficiency of public sector functioning and improving the state of public finance. This impetus came at the time when the number of prison sentences was on a sharp rise, and Slovakia faced challenges related to prison overcrowding" (Mihók, 2018, p. 30). However, in the justification of the draft EM Law proposal, the Ministry of justice (2014, pp. 2 - 3) stated that it [also] aimed to achieve these anticipated contributions, resp. the objectives:

- increased trust in alternative forms of punishment,

- Improved social inclusion of convicted persons and decrease of recidivism,

- Increased efficiency of work performed by probation and mediation officers,

- protection against domestic violence.

Thus a dichotomy between electronically monitored autonomous sentences and EM as a means to replace imprisonment, mentioned by the Boone and Herzog-Evans (2013) [and quoted in the previous section of this paper], seem to be present also within the Slovakian jurisdiction itself, resp. within the Slovak EM program itself. The Slovak program in principle allows for any use of EM that we found to be implemented in the EU as a form of an alternative to incarceration, i.e. in all the parts of a legal process (i.e. pretrial, front door and back door). The Slovak EM program can in general be applied also in relation to conditioned suspensions with surveillance (i.e. with the so called probation patrol), conditional releases from prisons and also the post-release phase when it involved the so called bilateral EM (i.e. EM of both offenders and their victims in cases involving domestic or sexual violence). With regards to conditioned suspensions with surveillance, the EM can be applied in cases when the conditions of suspension concern:

- bans requesting offenders not to approach, meet or communicate with their victims,

- bans to reside in particular municipality/ies,

- bans to attend public events,

- bans to consume alcohol (under the house arrests). 
According to our knowledge, EM cannot be applied in Slovakia with regards to conditioned suspensions with surveillance in cases when the conditions concern legal orders:

- to attend psychological treatments, alcohol/drug addictions related treatment and/or other specific social treatments,

- to leave certain residence and move to another residence,

- to get a job, apply for a job or attend a job related training.

This means that even should the so called 'holistic attorneys' (i.e attorneys who developed a form of therapeutic alliance with their clients) exist in Slovakia, they would be unable to advocate for any psychological and/or alcohol/drug addictions related treatments whose implementation could be monitored electronically under the currently valid Slovak legislation.

Within our desk research carried out within the IAEMPS project, we found out that the Ministry of Justice (2018) informed that there were only 113 sentences incorporating the use of EM since the EM program start in 2016. Apart from the house arrest sentences under which EM is mandatory whenever technically feasible, there were only 23 other sentences involving the EM which all concerned the so called bilateral scheme, i.e. EM of both offenders (released from prisons) and their victims, resp. former victims.

Within our desk research, we have also found out that Slovak defence attorneys were a part of the both working groups (WGs) established by the Ministry of justice in relation to EM: (1) the WG established in 2013, prior to the Slovak EM Laws and policies preparation and adoption (Ministry of Justice, 2013) and also (2) the WG established in 2018 with primary aims to evaluate the experience with the EM in Slovakia so far, and to elaborate opportunities for a more wide use of EM in Slovakia (Ministry of Justice, 2018). This finding, together with the presentation by Lewinbuk (2018), were the impetuses behind inclusion of defence attorneys into the first group of 'stakeholders' included in the pilot primary research of the IAEMPS project. This research was carried out by means of bilateral interviews with the selected Slovak judges, prosecutors, probation officers and defence attorneys, carried out in July - September 2018. In the following paragraphs of this section, we present only those results of this pilot research that concern the roles and ethics of defence attorneys in relation to EM introduction and implementation in Slovakia, for which the outcomes of bilateral interviews with the 9 respondents (mostly defence attorneys) have been used.

One of the key finding of the above described pilot research was that despite that the Slovak Criminal Procedure Code (the Act No. 301/2005 Coll.) has been adopted circa forty times since its effect into force in 2006, none of these amendments concerted the EM of offenders or accused persons. Between the year 2015 (when the Laws on the EM program were adopted) and the present, the amendments of the Slovak Criminal Procedure Code (CPC) were very frequent. However, despite that many of these recent CPC amendments (174/2015 Coll., 397/2015 Coll., 444/2015 Coll., 401/2015 Coll., 
78/2015 Coll., 440/2015 Coll., 398/2015 Coll., 91/2016 Coll., 125/2016 Coll., 316/2016 Coll., 152/2017 Coll., 236/2017 Coll., 274/2017 Coll., 161/2018 Coll., 161/2018 Coll.) contain the terms such as electronic signature, electronic communication or electronic elections (within certain legal bodies), none of them contains the term EM. The frequency of the recent $\mathrm{CPC}$ amendments, together with a completely lacking mentioning of the EM of offenders in the CPC, were mentioned within the bilateral interviews held within the IAEMPS project pilot research amongst the potential key reasons why the Slovak attorneys could not take an initiative role in fostering a wider application of EM after the Slovak EM program launch.

With regards to house arrests, the Slovak courts are obliged to apply the EM whenever it is technically feasible. From this reason, defence attorneys do not need to take any initiative in favour of EM in cases in which they presume house arrest as the most reasonable type of sentence to be proposed by prosecutors and chosen by the judges in court sentences. Under the current Slovak legislation, it is fully the role of the other actors (i.e. prosecutors, probation officers and judges) to initiate and carry out all the necessary investigations, evaluations and decisions concerning whether the EM is technically feasible given the specific conditions of permanent residences of accused persons). I.e. with regards to house arrest, paraphrasing the quote by Weisburd $(2015, \mathrm{p}$. 321) from the section 2 of this paper, the legal rights and practice of the Slovak prosecutors, probation officers and judges are fully focused on technical compliance with the EM program, and not on evaluating past and potential and optimal near future "offenders' trajectories". The IAEMPS project pilot research respondents, however, mentioned that the Slovak attorneys can foster the EM indirectly within pre-trial phase of criminal proceedings by means of mentioning that a house arrest seem an appropriate, resp. 'sufficient' sentence to achieve justice under given nature, extent and scope of a crime. At the same time, defence attorneys can also for ex. put emphasis on that their clients have a job and would be able to keep it under conditions of EM house arrest.

The IAEMPS project pilot research respondents were unaware of any specific right(s) of defence attorneys to foster EM within court proceedings. They mentioned that because the Criminal Law is a part of the Public Law (and not the Private Law), they can only initiate and perform such acts that are explicitly mentioned in the Slovak Criminal Procedure Code (CPC). As we have explained above, the current Slovak CPC does not contain any references to the EM. All the research respondents, however, referred to the fact that the Laws in principle allow defence attorneys to defence all their clients' rights, interests etc. during the court proceeding, inclusive of making proposals to impose the punishment with the use of the EM on condition that attorneys' clients are being prosecuted for such crimes for which the Laws do not allow sentences of imprisonment for more than two years. In the case of committing more serious offenses for which imprisonments could legally exceed two years, the Laws do not allow alternative forms of punishments that use the EM as a form of surveillance. Despite that all the defence 
attorneys interviewed within the IAEMPS project pilot research have already used their legal right to make a proposal in favour of the EM application within their defence activities during the court proceedings, we/they were unable to find a single case in which such a proposal by defence attorneys would be accepted by the judges. Majority of the respondents whose inputs have been used in a preparation of this paper stated that their up-to-date application of defences in favour of EM for their clients during the court proceedings seemed to lack any practical effect. Some respondents could only think of an option with a real leverage that defence attorneys could mention the EM within the court proceedings only should it 'reasonably fit' the defence of their clients in a direct response to questions or comments initiatively raised by prosecutors, judges or defence attorneys of victims specifically mentioning the EM.

Some defence attorneys interviewed within our pilot research mentioned that they had an impression that the judges were reluctant to take a proper account of their defences at the court proceedings in favour of the EM mainly from these two reasons: (1) it would create an additional administrative burden for them, and (2) that the judges were aware of a very limited personnel and financial/material capacities of the Slovak probations officers, a large amount of which is needed in order to apply the EM in a meaningful way. Some respondents have also mentioned an insufficient coverage of certain Slovak regions by the mobile telephone network(s). One of the possible hypothesis that resulted from the IAEMPS project pilot research is that the Slovak judges, even almost two years after the EM introduction by Law, still prefer traditions and practices established prior to the EM legislation introduction from the two reasons outlined above, and perhaps also lacking knowledge about the use of EM in Slovakia, lack of trust into this new mode of alternative punishments control, and/or simply that imposing traditional forms of punishments for minor crimes such as conditional imprisonment or sentences to impose mandatory work is perceived as both practically easier and less risky in terms of potential formal mistakes by the judges.

Specific legal rights of Slovakian defence attorneys related to fostering of the use of EM were mentioned by some IAEMPS project pilot research respondents only in relation to transfers of remaining [maximum half of] length of imprisonment into electronically monitored house arrest (note: such option is different than conditional release from imprisonment). Proposals of such transfers, however can, be submitted only by general managers of prisons, i.e. not by imprisoned offenders and/or their attorneys. Nevertheless, the some IAEMPS project pilot research respondents mentioned that the current Slovak CPC in principle allows defence attorneys (under the initiative or at lease consent of their clients) to prepare documents which can significantly help imprisoned offenders to succeed in their attempts to have remainders of imprisonment transferred into house arrests. Defence attorneys have both legal rights and practical capacities to prepare documents proving both (1) technical conditions of clients' permanent residences allowing EM of house arrests (i.e. reliable sources of electricity and telephone/GSM 
connection) as well as (2) that all the other people living at the same permanent residence would agree that an offender would spend a remainder of sentence in a joint residence with them. In the opinion of these IAEMPS project pilot research respondents, initiative preparation of the above mentioned documents (given the consent of clients) would be perceived to be in line with the current Slovak CPC, i.e. as opposed to any similar actions fostering EM house arrests within criminal proceedings.

An interesting insight was mentioned within the IAEMPS project pilot research concerning theoretical options to apply bilateral EM in Slovakia in order to monitor whether a potential offender would not approach/meet with potential victim(s) under the Private Law. The question discussed was "What would be a response of the judges and/or relevant legal authorities, should defence attorneys of both potential offender(s) of domestic/sexual violence and their potential victim(s), upon initiative/consent of them both, initiate that EM could be the best way to prevent an offence prior to any breach of the Criminal Law?". This potential future research question was discussed for example in the context of such escalations of conflicts of the divorcing couples that are not considered offences under the Criminal Law, or for example in the context of a response to any "still legal attempt of the so called date rape". It has been concluded that any potential further activities within the IAEMPS project in this regards need to be further consulted with the IAEMPS project stakeholders and ideally also relevant foreign experts interested in the issue (i.e. we therefore mention it also in this conference paper).

With regards to the code of conduct and ethics of the Slovak defence attorneys, the both the IAEMPS research activities in 2018 (i.e. desk research and pilot research by means of bilateral interviews) resulted in the finding that the code of conduct of the Slovak attorneys have not changed in relation or after the launch of the first EM program, but at the time of research the document adopted already in 2004 was still legally valid in this regards ${ }^{3}$.

\section{Concluding remarks}

The Laws and policies related to the EM have been prepared in Slovakia in $2014-2015$ and implemented in full since 2016 (Mihók, 2018), therefore they can be still considered new. In the theory, it should be "judges, defence attorneys, prosecutors and law enforcement [who] make front-end decisions that could support or undermine the impact of the new laws and policies" (James, Eisem and Subramanian, 2012, p. 827). Therefore, in respect to their roles in this regards, defence attorneys have been included in both (1)

\footnotetext{
${ }^{3}$ Rules of professional conduct for [the Slovak] lawyers, adopted by the Conference of [the Slovak] Lawyers on 19 June 2004. Note: this document was available in English at the webpage of the CCBE at:

https://www.ccbe.eu/fileadmin/speciality distribution/public/documents/National Regulations/DEON National CoC/EN Slovak Republic Rules of professional Conduct for Lawyers.pdf (accessed 19 July 2018).
} 
all the working groups initiated and created by the Slovak Ministry of Justice in a direct relation to preparation and evaluation of the first Slovak EM programme, and (2) the group of respondents of the first IAEMPS project pilot research conducted by means of bilateral interviews in July and August 2018. However, as we explained in more details above, the Slovak defence attorneys have not been provided with any specific new legal rights/roles in this regards by means of a Criminal Procedure Code (CPC) amendment (which is necessary for defence attorney to be eligible to act under the Criminal Law, resp. under the Public Law).

Similarly as perceived by Boone and Herzog-Evans (2013) when it comes to the different jurisdictions in Europe, our own desk research of the documents related to the Slovak EM program also suggested that there is a 'clear dichotomy' between (1) electronically monitored house arrests primarily aimed at replacing imprisonment with a cheaper alternative and (2) EM primarily aimed at reducing risks of recidivism, resp. aimed at protecting former victims of sexual or domestic violence. With regards to the former, our pilot research results suggest that the roles of defence attorneys in Slovakia are perceived as minimal, because (1) house arrests under the current Slovak EM Laws do not need to include any probation programs (whose compositions vis-à-vis the best interests of offenders could be influenced by defence attorneys who must know these interests and always act in favour of them), and (2) EM is mandatory for house arrests whenever it is technically feasible, and it it is fully the role of the other actors than defence attorneys (i.e. prosecutors, probation officers and judges) to initiate and carry out all the necessary investigations, evaluations and decisions concerning whether the EM is technically feasible.

Despite that the latter (i.e. reducing recidivism) is one of the proclaimed aims of EM introduction in Slovakia, our research results have not indicated that any new roles and relevant legal rights (within the CPC) would be provided to Slovak defence attorneys in relation to the first Slovak EM program. Within our desk research, we found out that "systematic review of the literature and evidence indicates that EM has been shown to produce positive effects [in reducing recidivism] for certain offenders (such as sex offenders), at certain points in the criminal justice process (post-trial instead of prison), and perhaps in combination with other conditions attached (such as geographic restrictions) and therapeutic components", and that the EM "may not work so well for other subgroups or under different conditions (Belur at al., 2017, p. 62). In the theory, a shift from 'classic penal attorneys' towards 'holistic attorneys', mentioned by Herzog-Evans (2013), should therefore be a relevant topic of further research in Slovakia in this regards, especially in relation to domestic and/or sexual violence. In light of the relevant research from the USA, reducing recidivism can hardly be achieved via EM if defence attorneys are not provided with specific legal rights to advocate for 'probation/correction/treatment plans' that are in the best interest of their clients, while the 
responsibility of public deputies/defenders are limited at educating other decision-making bodies about relevant defence considerations (Arredondo et al., 2001, p. 9).

The pilot research carried out within the IAEMPS project have not brought any results suggesting that the introduction of permanent EM program in 2016 would provide any impetuses for defense attorneys go beyond the long-term established traditions and practices of 'classic penal attorneys' (who primarily care to advocate for a minimal length of sentence, leaving the form of punishment fully to the judges/courts). In the other words, the introduction of the first EM program has not created any new impetuses for the Slovakian defence attorneys to consider shift of their thinking and defence activities towards what Herzog-Evans (2013) described as "holistic attorneys who develop a form of therapeutic alliance with their clients". In this regards, without any reference to foreign academic literature, the IAEMPS project pilot research included also bilateral interviews about 'theoretical options' to apply bilateral EM in Slovakia in order to monitor whether a potential offender would not approach/meet with potential victim(s) under the Private Law, with a conclusion that this theme needs a further expert discussion.

The IAEMPS project pilot research results suggested that, similarly as in the quoted academic literature about the situation in the USA, also in Slovakia "the courts, probation officers and prosecutors focus more on technical compliance with the EM program" rather than on the "offenders trajectories" (Weisburd, 2015, p. 321). Thus, the EM technology used in Slovakia "allows the probation officers to know whether or not the client is at home when he is supposed to be, but it does not let him know what the client is doing, either at or away from home, or what he is thinking" (Ibarra, 2005, p. 46). However, a research related to the concept of 'holistic attorneys' might be premature in Slovakia before defence attorneys are provided with legal rights related to the EM. The question whether defence attorneys could co-design probation programs whose success in implementation would be electronically monitored using a GPS-technology control of 'offenders trajectories' is considered to be premature in Slovakia by the IAEMPS project team, given the current legal context in Slovakia (outlined above in this paper).

The assumptions related to rather very low use of EM in Slovakia in 2016 and 2017, presented by the Slovak Ministry of Justice (2018) [and not dealt with in this paper] in our view confirm the point of view by Lewinbuk (2018) that the research in this field should also include "an analysis of the reasons behind established traditions and practices" in Slovakia. And, moreover, also an analysis of expectations put in front of defence attorneys (from both their clients and 'the relevant judicial authorities'). Within the IAEMPS project, such analyses are considered to be carried out in 2019. The practical aim of this presentation/paper is to help the IAEMPS project team in getting feedback on the results of the pilot research presented in this paper (as they could be used as background materials for these analyses in 2019), and also to approach as wide spectrum of foreign academics in the field of Law as feasible. 


\section{Funding}

The research leading to these results has received funding from the Slovak Research and Development Agency within the project titled 'Interdisciplinary approach to electronic monitoring of accused and convicted persons in the Slovak environment' (acronymed IAEMPS) under the contract No. APVV 15-0437.

\section{REFERENCES}

APAV (2015) Mapping the legislation and assessing the impact of Protection Orders in the European Member States (POEMS). National Report Portugal. Available at: http://poems-project.com/wpcontent/uploads/2015/02/Portugal.pdf (accessed 17 July 2018).

Arredondo, D., Kumli, K., Soto, L., Colin, E., Ornellas, J., Raymond, D., Davilla, D., Ewards, L. and Hyman, E. (2001) Juvenile Mental Health Court: Rationale and Protocols. Juvenile and Family Court Journal 52(4) 1 - 19. DOI: 10.1111/j.1755-6988.2001.tb00047.x.

Boone, M., der Kooij, M. and Rap, S. (2016) Electronic Monitoring in the Netherlands [The EMEU project report]. Available via: http://emeu.leeds.ac.uk/reports/ (accessed 10 January 2018).

Boone, M. and Herzog-Evans, M. (2013) Decision-Making and Offender Supervision in Europe / Presentation of the group. Available at: http:/www.offendersupervision.eu/wpcontent/uploads/2013/07/WG2-Briefing-2013.pdf (accessed 17 July 2018).

Belur, J., Thornton, A., Tompson, L., Manning, M., Sidebottom, A. and Bowers, K. (2017) A systematic review of the effectiveness of the electronic monitoring of offenders. London: University College. Available http://whatworks.college.police.uk/Research/Systematic Review Series/Documents/Electronic moni toring SR.pdf (accessed 18 July 2018).

CCBE (2013) Charter of core principles of the European legal profession and code of conduct for European lawyers [Edition 2013]. Available at: https://www.ccbe.eu/NTCdocument/EN CCBE CoCpdf1 1382973057.pdf (accessed 18 July 2018). [note: CCBE stands for 'The Council of the Bars and Law Societies of the European Community'].

Daily Herald (2017) Electronic monitoring out in Kane's final budget vote. Available at: http://www.dailyherald.com/news/20171114/electronic-monitoring-out-in-kanes-final-budget-vote (accessed 11 July 2018).

Goldsmith, J. (2016) EAW-Rights. Analysis of the implementation of and operation of the European Arrest Warrant from the point of view of defence practitioners [the Final Report of the AW-Rights project, published by the Council of Bars and Law Societies of Europe (CCBE) and the European Lawyers Foundation (ELF)]. Available at: https://www.ccbe.eu/fileadmin/speciality distribution/public/documents/CRIMINAL LAW/CRM projec ts/EN CRM 20161117 Study-on-the-European-Arrest-Warrant.pdf (accessed 18 July 2018).

Herzog-Evans, M. (2013) Comparative research on decision-making: Reflections on the Bratislava meeting (from France). Available at: http://www.offendersupervision.eu/blog-post/comparative-research-ondecision-making-reflections-on-the-bratislava-meeting-from-france (accessed 17 July 2018). 
Ibarra, P. R. (2005). Red flags and trigger control: the role of human supervision in an electronic monitoring program. Sociology of Crime, Law, and Deviance, 6(1) 31-48. DOI:10.1016/S1521-6136(04)060038.

James, J., Eisem, L.-B. and Subramanian, R. (2012) A View from the States: Evidence-Based Public Safety Legislation. Journal of Criminal Law and Criminology 102(3) 821 - 850. ISSN 0091-4169.

Lewinbuk (2018) Comparative analysis of ethical boundaries and regulations for lawyers in the United States, European Union and Russia / legal profession in a comparative context [oral presentation at the 2nd Law \& Political Science Conference, Prague, 13 June 2018]. Abstracted in: Proceedings of the 2nd Law \& Political Science Conference (Prague), p. 7. ISBN 978-80-87927-62-5.

MacKenzie, D. (2006) What Works in Corrections: Reducing the Criminal Activities of Offenders and Deliquents (Cambridge Studies in Criminology). Cambridge: Cambridge University. ISBN: 978-0-51149947-0.

Mihók, P. (2018). Electronic monitoring of offenders and accused persons in Slovakia in the international and European context. In: Proceedings of the 2nd Law \& Political Science Conference (Prague), pp. 22 - 33. DOI: 10.20472/LPC.2018.002.008.

Ministry of Justice [of the Slovak Republic] (2018) Odborná pracovná skupina začala s analýzou možností rozsiahlejšieho využívania elektronických náramkov. Available at: https://www.justice.gov.sk/Stranky/aktualitadetail.aspx?announcementID=2364 (accessed 17 July 2018)

Ministry of Justice [of the Slovak Republic] (2014) Návrh zákona o kontrole výkonu niektorých rozhodnutí technickými prostriedkami a o zmene a dopInení niektorých zákonov / Dôvodová správa, všeobecná čast' [The proposal of Act on the control of the execution of selected decisions by means of technical instruments / The reasoning statement, general part]. Annex to the document dated 3 November 2014, submitted to the session of the Government under the number 40611/2014/120, and approved by the Resolution of the Government of the Slovak Republic no. 4 on 7 January 2015.

Ministry of Justice [of the Slovak Republic] (2013) MS SR pripravuje legislatívne zmeny na podporu alternatívnych trestov. Available at: https://www.justice.gov.sk/Stranky/aktualitadetail.aspx?announcementID=1801 (accessed 17 July 2018)

Pinto de Abreu, C. (unknown year) The role of the practising lawyer in Electronic Monitoring in Portugal [slides from the presentation]. Available at: http://carlospintodeabreu.com/public/files/the role of the practising lawyer.pdf (accessed 17 July 2018).

Texas Criminal Justice Policy Council (1986) Electronic monitoring of offenders. Available at: https://www.ncirs.gov/pdffiles1/Digitization/102513NCJRS.pdf (accessed 11 July 2018).

Weisburd, K. (2015) Monitoring Youth: The Collision of Rights and Rehabilitation. lowa Law Review. 101(1) 297 - 341. ISSN 0021-0552.

Windham County Sheriff's Office (2016) Electronic Monitoring Program (Rev: 9/16/16). Available at: https://legislature.vermont.gov/assets/Documents/2016/WorkGroups/Corrections\%20Oversight/S eptember\%2028/W Sheriff\%20Keith\%20Clark Electronic\%20Monitoring\%20Program\%20 9-282016.pdf (accessed 11 July 2018).

Windham County Sheriff's Office (2017) Electronic Monitoring Program (Rev: 11/8/16). Available at: https://legislature.vermont.gov/assets/Documents/2018/WorkGroups/Senate\%20Judiciary/Electro 
nic\%20Monitoring/W Keith\%20Clark Electronic\%20Monitoring\%20Program 1-17-2017.pdf (accessed 11 July 2018). 